\title{
LEARNER AUTONOMY IN THE LIGHT OF FREIRE ${ }^{1}$
}

\author{
(Autonomia do aprendiz à luz de Freire)
}

\author{
Christine Siqueira Nicolaides \\ (Universidade Federal do Rio Grande do Sul) \\ Vera Fernandes \\ (Centro Especializado em Seleção - CES/UFPel.)
}

\begin{abstract}
Concepts on autonomy in language learning usually converge to the responsibility over one's own learning. This paper aims to emphasize that learner autonomy is also a matter of getting involved with the social environment in which the learner is inserted in. This conception will be analyzed in the light of Freire's Critical Pedagogy. OTÁVIO, considered a "rebel" by his own teachers, is brought up as a case study to illustrate kinds of transformation, which might happen under the influence of the environment and of the opportunities generated in it.
\end{abstract}

KEY-WORDS: autonomy; Critical Pedagogy; language learning; social context.

RESUMO: Concepções sobre autonomia do aprendiz geralmente convergem para a responsabilidade sobre seu aprendizado. Este artigo tem por objetivo enfatizar o fato de que autonomia do aprendiz é também uma questão de envolver-se com o ambiente social no qual está inserido. Essa concep̧ção será analisada sob a luz da Pedagogia Crítica de Freire. OTÁVIO, considerado um "rebelde" por seus próprios professores, é trazido à tona como um estudo de caso para ilustrar tipos de transformações que podem acontecer influenciadas pelo meio e pelas oportunidades nele geradas.

PALAVRAS-CHAVES: autonomia; Pedagogia Crítica; aprendizado de língua; contexto social.

\section{Introduction}

This paper is an attempt to explore into some depth a few of Freire's ideas concerning autonomy. In the introduction of his work "Pedagogy of

\footnotetext{
1 We are especially grateful to our colleagues Phil Benson, Rosalia Garcia and Teresinha Sprenger for their valuable comments on this paper.
} 
Freedom" (1988), Stanley Aronowitz describes it as Paulo Freire's 'last testament', probably his most important work after "Pedagogy of the Oppressed" (1973). Freire emphasizes that, as members of society, it is extremely important the awareness of our own actions/performance. In simple words - every decision and choice made, every path taken, every reaction to our partners' affliction or happiness will make a difference in our group.

After discussing some autonomy concepts, we relate the theme with some of Freire's ideas. For that, we use some of the author's arguments which reinforce the need of each member of our society to be conscious of his $^{2}$ role in it. Ideally, being an autonomous learner is not only a question of becoming independent, but of being someone who focuses his own learning also on the interest of his peers.

From our point of view that is an important issue which should be regarded all the way through school years. That is the place where we learn to socialize, interact and understand we have free will to improve (or not) the environment which we are inserted in.

Bringing this principle into the reality of our educational scenario, we use some data generated by OTÁVIO's learning experience during his training to become an English teacher. Our intention is showing some transformations which may occur during the schooling process, influenced by the environment and its opportunities.

\section{Discussing autonomy concepts}

Presuming that autonomy is an essential human condition to the full development of the individual, we consider it as one of the main points in the educational context. Human beings were born to be autonomous. This can be easily verified while you watch a baby trying to do simple things as spoon-feeding himself, giving his first steps, and even later on, when becoming an adult, looking for his financial independence. It seems that this innate inclination is unfortunately not stimulated through out the child's school years. Children are usually very excited and fascinated by

2 When we use he/his/him/himself we are actually referring to both male and female learners. 
new knowledge and experiences. Somehow the system, aiming to discipline them, ends up "domesticating" its children and smothering their creativity, and consequently their autonomy in terms of learning.

Due to its relevance, we should review the conception of the term autonomy. Beginning from a dictionary entry, autonomy is defined as: "1.independence or freedom, as of the will, of the individual". Also as "the condition of being autonomous; self-government, or the right of selfgovernment; independence" (one's actions, etc: the autonomy of the individual. 2. The condition of being autonomous; self-government or the right of self-government; independence. 3. A self-governing community (Webster 1994:101).

In terms of origin, it comes from Greek, autonomia, from the term autocephaly (Britannica 2007). Actually, the Orthodox Churches were said to be autocephalous after achieving their independence when the Ottoman Empire fell, and parted from the Constantinople Patriarchate, which has remained under Turkish jurisdiction until the present days.

Today autonomy has become one of the indispensable keywords to the formation of a professional prepared to face new work markets and different life styles.

Aiming to clarify better the concept of autonomy it is relevant to briefly comment three parallel ideas that usually come up not only in the area of Applied Linguistics, as well as Education, Philosophy, Sociology, Anthropology and even in everyday discussions - freedom, independence and responsibility.

Although the distinction of limits among these terms and autonomy is subtle, it is necessary to consider the different nuances they present.

The concepts independence and autonomy may appear as synonyms; the first one can be understood as "state or condition of whom or what is independent, of whom or what has freedom or autonomy" (Aurélio 1999:1099). Not everybody agrees with this statement though. This is the case of the $\mathrm{PCN}^{3}$ on Brazilian mother tongue (Portuguese) (1997:38)

\footnotetext{
3 Parâmetros Curriculares Nacionais are an interpretation of the major Brazilian law which rules over education in different areas of knowledge.

4 The authors are responsible for the translations through out this article.
} 
It is important to stress that autonomy construction should not be mixed up with independence attitudes. The student may be independent to perform a series of activities, meanwhile his internal resources to self-government are still precarious. Independence is an important manifestation for development, but it should not be confused with autonomy.

Still, according to the PCN on Brazilian mother tongue autonomy refers to $(1997: 31)$ :

Capacity to take sides, elaborate personal projects and participate comparatively in collective projects, be aware, get organized in terms of chosen aims, self-govern, participate in the management of collective action, establish criteria and elect ethical principles etc. In other words, autonomy deals with a relationship, wholly integrated with different life dimensions, which involves intellectual, moral, affective and socialpolitical aspects.

This way we advocate the distinction between autonomy and independence, especially in the Applied Linguistics area, considering that the second concept relates more to independent attitudes. To become autonomous, independence is necessary; yet to be autonomous it is still necessary that a person is aware of the social context he lives in. He is influenced by the environment as well as being its modifying agent. This concept is also connected to the concept of responsibility. To act autonomously or even independently is a sine qua non condition to be responsible. Aurélio (1999:1754) defines a responsible person as "one who answers for his own or other's acts; that answers legally or morally for someone's life, wellbeing etc; person responsible (for something or somebody)", consequently, autonomy implies responsibility for the social environment he is in.

Every moment we are prone to learn/acquire new knowledge we have the choice to use this new knowledge in a responsible way (or not). Considering that to be autonomous it is necessary to be responsible to what happens to us, as well as to what happens around us, responsibility and autonomy although not synonyms are closely tight.

In the same line of thought, Scharle and Szabó (2002:3) state that autonomous learners are the ones

... who accept the idea that their own efforts are crucial to progress in learning, and behave accordingly... Responsible learners do not have to be especially keen on team work, but they are willing to cooperate with the teacher and others in the learning group for everyone's benefit. 
And last, but not least, there is the concept of freedom. Once more using the dictionary (Aurélio 1999:1209) "each one's faculty to decide or act according to one's own determination" suggests that freedom consists in acting the best possible way without necessarily considering the social environment, as well as the consequences of our actions. In a second view "power to act, in an organized society, according to one's own determination, within the limits imposed by established rules: civil freedom; press freedom; teaching freedom", the constrictions which must be respected because we live in a society are clear.

Although both interpretations are correct, the second one seems to be more adequate to our purpose in this paper. Again, the main difference concerns the social environment.

The literature in the area of Applied Linguistics presents a variety of concepts related to autonomy, which are not necessarily in opposition to one another, but often focus different aspects, as will be shown next.

Probably the most classical concept of autonomy, still adopted by researchers in the area, is the one proposed by Holec (1981:3) - "the ability to take charge over one's own learning".

On the other hand, some authors conceive autonomy as an educational practice, as for Boud (1988:1), who considers it, besides an educational goal, also "an approach to a pedagogical practice". Under a wider perspective, Dickinson (1987:4) also presents autonomy as an educational praxis, in which it is "essentially a matter of learning attitude", and it is not confined to one method but is an educational objective. The completely autonomous learner would make every decision about his learning, from planning, through execution, going as far as deciding on his own evaluation.

It is relevant, though, to bring up Auerbach (2000), when approaching "participatory pedagogy". The author does not talk specifically about learning autonomy, but about an educational approach. She emphasizes that, if on one hand, learners have their goals and individual differences, on the other teachers have their own objectives, their own understanding of the pedagogy which is more efficient to L2 acquisition, as well as the power to determine these procedures. According to the author, this is a principle often disregarded by Applied Linguistics' researchers (cognitivists), who focus only on the learners and their mental processes, ignoring the social context because they defend student-centered learning. 
Auerbach argues that "participatory pedagogy" requires a focus on the social context of $\mathrm{L} 2$ acquisition, and the power relations inserted in it, once it is shared by learners and teacher. That is, the idea is not to substitute the teacher's role for the student's but to stress the learning context, taking its peculiarities into account.

The idea of Participatory Pedagogy can be transferred to the concept of learning autonomy, inasmuch as it also emphasizes the importance of the social context. Dam and Legenhausen (1999) defend the idea that autonomy is directly related to the social context, while traditional concepts focus on the individual. Otherwise stated, it seems many of these concepts converge to the idea that being an autonomous learner has to do specifically only with the learner himself.

From our viewpoint, autonomy is a wider concept which can be developed through different paths according to learners' needs, styles and the context in which he is. This is an interesting point that needs to be brought up since we can find several examples of self-access centers or independent learning centers which are sometimes quite sophisticated in terms of technology, but do not necessarily aim at autonomy development of its learners. If we do not pay attention to this fact, we are merely repeating the models of the former language labs (behaviorist ones), where the main objectives were to improve intonation or pronunciation of the student, so it would resemble that of a native speaker, among other things. This means much more emphasis on form than on meaning. Interaction among the participants is not necessarily developed.

Considering the arguments we have brought up, we adopt Nicolaides' definition of autonomy. The author believes that, in order to be autonomous the learner should be able to take charge over his own learning, and ideally needs to (Nicolaides 2003:39) be capable to:

- define his aims;

- understand his role as a learner responsible for the process of search and acquisition of his own knowledge;

- select ways to search for his knowledge developing abilities and skills to work independently in contexts that are different from the academic one; 
- detect his difficulties and look for solutions, while exercising greater control over his own learning;

- self-evaluate, not only at the end, but during the learning process.

These requirements agree with the traditional concepts mentioned so far. Nonetheless, the author also proposes the following:

- develop the capacity to exercise autonomy as a learner within the opportunities offered by the context in a responsible way, and, therefore, become aware of his role as a modifier of his social environment.

In the light of the challenging Critical Pedagogy, proposed by Freire, we can find some support to corroborate the idea that learner autonomy also refers to a relation of the individual with his environment. Thus, next section will be enriched with some of Freire's thoughts somehow related to autonomy.

\section{Relating autonomy to some aspects of Freire's Critical Pedagogy}

It is important to mention that the word autonomy is sometimes substituted by freedom, in Freire's work - Pedagogia da Autonomia is translated into Pedagogy of Freedom. Our interpretation is that the term freedom for Freire also implies behaving freely within the limits imposed by responsibility.

\subsection{Reflection is essential to action and our actions have influence in society}

In Pedagogy of Freedom, Freire discusses what is involved in education and in becoming an educator. He proposes a progressive perspective, defined as "a point of view which favors the autonomy of the students" (1998:21). He places his ideas in the present school reality, within the context of neoliberal pragmatism, which he criticizes. The theoretical and normative foundation of his work is the pursuit of education, aiming at making man more human. 
In the attempt to apply this philosophy into reality, we accept Freire's (1970) teaching, when he says reflection is essential to action, which means helping people to become aware of their own actions.

In any situation, reality does not change by itself. There is the need for the critical intervention of the people who belong to a specific environment through praxis. Therefore, while bringing Critical Pedagogy to the classroom, as teachers, we have the role to explain learners the consequences of their own actions. It is through the reflection over their capacity to transform reality that we will be truly educating them for their own liberation. This way, being autonomous is not a matter of being responsible only for our individual knowledge and its development, but mainly for how this knowledge and how our attitudes may influence this process to improve society.

Also, regarding his view on Critical Pedagogy, the author stresses the relevance of not losing hope on how we think education should be, surrendering to current policy regimens. Even having utopian ideals as educational goals, we should bind to the effort of humanizing the individual. As Freire states (1998:69-70):

... the absence of hope is not the "normal" way to be human. It is a distortion. I am not ... first of all a being without hope who may or may not later be converted to hope. On the contrary, I am first a being of hope who, for any number of reasons, may thereafter lose hope. For this reason, as human beings, one of our struggles should be to diminish the objective reasons for that hopelessness that immobilizes us.

Putting these thoughts together, we believe that through autonomy development we are guiding the individual to improve his reality - making him aware of his obligation to strive for the freedom and the change of the reality of his context, despite all the constrictions he may face. This can only happen by means of deep reflection accompanied to action so as not to fall into a void.

\subsection{Teaching is not only transmitting knowledge}

Gadotti (2007), a specialist in Freire's work, points out an interesting aspect of Critical Pedagogy. The author explains that Freire does not view education as the mere transmission of content from teacher to student. He 
sees it as the beginning of a dialogue, which means that teaching also concerns learning. In Freire's own words (1998:31):

To learn ... precedes to teach ... to teach is part of the very fabric of learning ... there is no valid teaching from which there does not emerge something learned and through which the learner does not become capable of recreating and remaking what has been thought ... teaching that does not emerge from the experience of learning cannot be learned by anyone.

This is a profound construct through which Freire defies us to stimulate - teaching through the development of a dynamic and all ongoing dialogical process. This means teaching can not happen without learning. That demands:

- respect for the learner's viewings of the world;

- methodological rigor, research;

- critical thinking about our own educational practice;

- ethics;

- coherent behavior to what you think and preach;

- risk-taking and acceptance of the new, while rejecting any form of discrimination and

- recognition of learners' cultural identity.

A few pages later, the author completes his line of thought by saying that (1998:49):

When I enter the classroom I ought to be someone who is open to new ideas, open to questions, and open to the curiosities of the students as well as their inhibitions ... I ought to be aware of being a critical and inquiring subject in regard to the task entrusted to me, the task of teaching and not that of transferring knowledge.

Teaching for Freire demands accepting new challenges and refusing all kinds of discrimination that separate people into races, social and economical classes, beliefs and so on. It has also to do with the idea that we are never complete; in spite of the awareness we are conditioned beings, there is always the chance to intervene in our environment. Most important of all, educating means having respect for learner's autonomy. 
Learning is a constructivist process owned by the learner and facilitated by the teacher while interacting with student, which includes respect for the student's opinions. Freire disdains the idea of education as "banking". This model refers to education understood to be merely the transfer of pre-existing knowledge from teachers to students; metaphorically speaking teachers make "deposits" into the relatively empty accounts of the students; these deposits take the form of "cultural capital", which when accumulated confer the privileges of traditional education.

Critical Pedagogy proposes that the educator learns from the learner, just as the learner, in his turn, learns from the educator. In sum, pedagogy should not be centered neither on the teacher nor on the learner but on learning, situated in a certain context. New learning is produced inasmuch as the knowledge of both learner and teacher is shared. In this way, nobody is definitely and completely educated. Each person, according to his individual needs, learning styles, previous experiences and beliefs, together with others, can learn and find new paths and niches from life's realities. Education, consequently, becomes a process of collective and continuous formation.

This way, once more, autonomy plays an important role in Critical Pedagogy. If the learner is also considered a source of knowledge, he has to be autonomous enough to bring his own experiences into the classroom. He can only do this if the learning situation allows him to.

\subsection{Learners should see educators as oppression liberators and not as authoritarian models}

In transferring the idea just mentioned to our practice, we must understand that, besides stimulating learners to become aware of their own actions, and to comprehend that knowledge is collectively produced, and not immutable, it is also important to foment an environment in which students see us as oppression liberators. As he states (1970:1):

True generosity consists precisely in fighting to destroy the causes which nourish false charity. False charity constrains the fearful and subdued, the 'rejects of life' to extend their trembling hands. ....

This lesson and this apprenticeship must come, however, from the oppressed themselves and from those who are truly in solidarity with them... Who are better prepared than the oppressed to understand the terrible significance of an oppressive 
society? Who suffer the effects of oppression more than the oppressed? Who can better understand the necessity of liberation? They will not gain this liberation by chance but through the praxis of their quest for it, through their recognition of the necessity to fight for it.

As educators, if we provide an authoritarian context where the teacher is seen as the "owner of knowledge", and the learner its reproducer, it is very likely that this learner, if and when he is empowered, will repeat the same pattern. As university teacher educators it is our role to help our student teachers become oppression liberators in their future careers.

Freire's pedagogy is centered in a sound allegiance between educator and learners. It deals with enlightening oppressed people in such way they can get engaged into the struggle for their personal liberation. That means getting rid of the oppressor as a model of what should or should not be done in their own lives.

Freire underlines that preparing teachers is much more than simply training them in the use of skills. The formation of teachers in learning how to teach is extremely relevant. Mastering the content is not sufficient. Our role as educators is also the one of oppression liberators.

Again, helping students to become more autonomous is the role of a teacher who believes that his student is also a collaborator in the production of knowledge. This can only happen if teacher and learners are on the same level, where nobody oppresses, no one is oppressed.

\section{Awakening learners' awareness}

As mentioned before, in an attempt to illustrate what we are here advocating, we will describe some aspects of OTÁVIO's trajectory as a language learner, while being prepared to become an English teacher. The data that is about to be shown were extracted from two studies based on the same participant in two different moments - as a language learner (Nicolaides 2003) ${ }^{5}$ and as an in-training teacher (Fernandes 2005) .

\footnotetext{
5 Interviews

6 Weblogs, class observations by the trainee's supervisor, written questionnaire and final report on the in-training period.
} 
There could be many other case studies to use here as examples of what we are trying to point out. There were a few peculiarities about OTÁVIO that called our attention, though.

He was labeled by his teacher as an apt student with a taste for the English language, although he has shown many difficulties in adapting to the academic world. These difficulties concerned his way of dealing with responsibilities and chores he was asked to perform in the learning context, and also to attitudes that marked him as a "rebel", who did not behave accordingly.

He was an extremely interesting participant in regards to autonomous learning. OTÁVIO has learned English by himself, without anybody's help, and outside of any formal learning environment, which can be verified through his own words:

Transcription $33^{7}$ : meeting $2-08 / 29 / / 01$

$\mathrm{O}^{8}$ - Yes, my case is different. I was bombarded since I was very little.

$\mathrm{R}^{9}-$ Bombarded by whom?

$\mathrm{O}-\mathrm{Uh}$, by the TV. Uh, it's a long story. My father worked for Bayer, you know. He was, is a sales manager. And then, Bayer gave him a videocassette, like a bonus. This was around 1973, when...

...

O - Yeah. Uh, and so, since I was little, I've spent, let me see, from 5 to 16 years old watching videos.

$\mathrm{R}$ - Do you have brothers and sisters?

$\mathrm{O}-\mathrm{No}$, I'm an only child. I think because I was an only child, so I didn't have a brother to ... stay with me.

$\mathrm{R}$ - So, you watched movies?

$\mathrm{O}$ - Yeah, even when I wasn't able to read yet.

Analyzing OTÁVIO's words, we can perceive a feeling of loneliness concerning his experience as an English learner. Being an only child and not having anybody to play with, he solved his lack of companionship by watching movies. It seems he did not have the experience to learn English by the interaction with others.

\footnotetext{
7 The interviews were originally done in Portuguese. After being transcribed, they were translated into English by the authors.

8 O refers to OTÁVIO.

$9 \mathrm{R}$ refers to the researcher.
} 
When he began his undergraduate studies, being an English teacher was not an option - he was simply studying English because it was something he already "knew"; it was much more a matter of taking advantage of a knowledge he already possessed.

However, as time goes by, OTÁVIO develops a different view of his role.

Transcription 22: meeting 5 - 11/18/01

$\mathrm{O}-$ Well, I got to the conclusion that my thing is really to be a teacher, because honestly this research thing is not my thing.

$\mathrm{R}-\mathrm{But}$ is this a reason for believing you can be a teacher, or is there something else? $\mathrm{O}-\mathrm{No}$.

$\mathrm{R}$ - Because one thing doesn't exclude the other, right?

$\mathrm{O}-\mathrm{No}$, because I have a, it's not painful to teach a class, I get along well with, I have...

$\mathrm{R}-\mathrm{Uh}, \mathrm{uh} .$.

O - Everybody tells me I'm patient. I don't, ok, I just say so, I'm calm, I don't get stressed if I see people are not learning.

$\mathrm{R}$ - Do you like to share your knowledge with other people?

$\mathrm{O}$ - Well, it's not that I like to share, I like to be asked. Because being a teacher is not something that bothers me, to explain things to the others.

As it can be observed, by sharing his previous knowledge of the target language with his colleagues, OTÁVIO realizes he might have the aptitude to teach.

In this sense, the educational system is very important to the learner's academic path, once it should guide him not only to acquire new knowledge but also through the roads he might take.

It is interesting that OTÁVIO has gone through this change only out of the classroom context. In the classroom, under his teacher's perspective, he is considered non-collaborative and not very interactive. OTÁVIO is very aware of this attitude and continued to act this way during the whole course. Out of his classroom, though, he is seen as a helpful classmate, and seems satisfied with this role.

Data do not reveal who or what really helped in this transformation. What we can affirm is that he changed his attitude once he had the opportunity and the need to put this ability into practice. Ability he, himself, was not aware so far he had it. 
What happened to OTÁVIO leads us to believe that autonomy is also a question of opportunity. Because he felt useful in his environment, he realized that things could be seen from a different perspective.

It is possible to link OTÁVIO's situation to the first of Freire's thoughts here presented. As he had the chance to reflect over his practice, he was conscious he could become a teacher. So reflection was essential to action and his action influenced his environment, that is, his colleagues had another learning opportunity.

Later on, when he is finally charged with encharged of the teaching process during his in-training praxis, it is also possible to relate his practice with Freire's pedagogy.

It is relevant to verify the way OTAVIO reflects over his own teaching through a weblog ${ }^{10}$ he sent his supervisor:

Weblog 5 - September 29, 2005.

Analyzing my teaching method, I see it as very peculiar, because I avoid repeating old models "memorize, don't think", which are very common in the classroom. It is working.

It is clear the concern OTÁVIO has about the way he teaches. Whether his method is adequate or not, it seems he is worried about analyzing his practice, and how it influences the learning environment

As mentioned before, in principle, every human being is autonomous, once he can learn hundreds of chores during his lifetime and, eventually, he is able to perform them without anybody's help. In language learning, it cannot be different; learning happens by means of social interaction, if there is such an opportunity. When there is not, as it was the case during a period of OTÁVIO's life, learning can still happen in other ways (not having brothers or sisters to play with and spending a great deal of time watching videos). So, being in the academic environment was paramount in changing his perspective, which emphasizes the importance of the institutional role. In sum, OTÁVIO's example shows us that autonomy is linked to the learner's context.

10 Weblogs - these are emails sent by trainees immediately after teaching each of their classes with their main impressions about the class. 
As to the affirmative which Freire defends - teaching is not only transmitting knowledge - we can also detect it in OTÁVIO's discourse while describing one of his classes, as an in-training teacher.

Weblog 8. November 8, 2005.

I try to stimulate them to ask questions and to solve their doubts, even if they have nothing to do with the content of the book. This way, besides stirring their interest, I can use their questions as a link to develop the contents.

It is possible to observe that having in mind the content he was developing, OTÁVIO thinks he allows students to contribute with their own questions, and inasmuch as possible tries to incorporate them in the learning process. Translating this into Freire's words it means respecting learners' reality. It is not only a matter of reproducing pre-established knowledge but of making learning experience meaningful to them.

On the other hand, the situation might be far more complicated than it seems. He developed a sense of autonomy during his school years, due to opportunities to share his knowledge with his classmates and to reflection. This was not enough, though, from our point of view, to make him a committed educator. Let us see an example taken from the supervisor's notes ${ }^{11}$ from the same class:

Class observation on November 11, 2005

I am under the impression he faces the in-training period as a short-lived activity, with no interest, no meaning, in an absolutely superficial way. It's a waste of time, just the fulfillment of an academic requirement. Undoubtedly, if he were more interested and focused on his work, he could have done a much better job, especially considering the optimal conditions (motivated and disciplined students, audio-lingual facilities, textbook).

Therefore, it seems autonomy may develop in some aspects to a certain degree. Here a complex chain of feelings is involved, varying from personality factors to learner motivation to search for knowledge, wishing or not to share it with others in some circumstances.

\footnotetext{
11 Future language teachers must go through an in-training period which is supervised by a teacher, here designated as "supervisor".
} 
Finally, bringing up a third principle advocated by Freire - learners should see educators as oppression liberators and not as authoritarian models - it seems that OTÁVIO's words express this conviction.

Weblog 10. November 22, 2005

A method that is working for conversation is making the students feel relaxed, this way they forget their fears to talk and can better pronounce the sentences.

Far from being an oppressor, OTÁVIO shows through his words that he is trying to ease his students' work. He helps them to loose themselves so they can easily deal with the language they are learning. This can be corroborated by his words, when answering a written questionnaire about teacher beliefs on autonomy, before beginning his in-training period.

Questionnaire - August 5, 2005

Question - Which attitudes, behaviors and approaches you have experience during your university years which you will not use with your own students?

Answer - I will deal with everyone equally, without privileges. I will not label my students without knowing them well and will not judge them at first sight.

Later on, already as a trainee, OTÁVIO keeps showing that he does not act like an oppressor. His supervisor's notes show his flexibility while negotiating with students concerning class management:

Class observation on November 11, 2005

Students ask him to postpone the test from tomorrow to next week. He complies.

In the end of the in-training period, OTÁVIO still shows his intent to help students become critical thinkers, not restricting their opinions but making them come up. Let us see what he says in a weblog sent to his supervisor:

Weblog - November 28, 2005

The students themselves have already told me that the way I have them reflect over the content and the learning process are having good results.

In the beginning of December, in another weblog, he states:

Webblog - December 4, 2005

I have made constant changes in my lesson plans; I have done a lot of improvement in the exercises and in the way I approach the contents, considering students' performances. Some changes are made even during the class. 
Again OTÁVIO is revealed as not aiming to oppress his students, on contrary, he tries hard to facilitate their learning.

\section{Final remarks}

Going back to Critical Pedagogy, OTÁVIO changed his perspective over the learning environment, though not necessarily because of classroom opportunities provided by the teacher. What data show us is that his contact with classmates made him realize that he could become a teacher, and could be pleased with this.

At the same time, it seems OTÁVIO was not able to become a desired autonomous learner according to our concept, neither an autonomous teacher, considering he did not show enough responsibility towards his professional performance. As Freire states (1970:4):

The solution cannot be achieved in idealistic terms. In order for the oppressed to be able to wage the struggle for deliberation they must perceive the reality of oppression not as a closed world from which there is no exit, but as a limiting situation which they can transform.

Accordingly, it looks like OTÁVIO did not have enough opportunity to develop his potential as an autonomous educator. Hopefully that will happen through his professional years. Here we underline the importance of continued education. Just letting students out of the classroom after they graduate, with no support, is not an efficient way to form a teacher. Again using Freire's words (1998: 23)

... teacher preparation should go beyond the technical preparation of teachers and be rooted in the ethical formation of both selves and history. But it is important to be clear that I am speaking not about a restricted kind of ethics that shows obedience only to the law of profit. On the contrary I am speaking of universal human ethic, and ethic that is not afraid to condemn the kind of ideological discourse I have just cited. Not afraid to condemn the exploitation of labor and the manipulation that makes into a rumor into truth and truth into a mere rumor... The ethic which I speak is that which feels itself betrayed and neglected by the hypocritical perversion of an elitist purity, an ethic affronted by racial, sexual, and class discrimination. For the sake of this ethic, which is inseparable from educative practice, we should struggle whether our work is with children, youth or adults. 
We are aware of how unique the case stated here is, which we think is quite natural, since we are dealing with human beings, and therefore with different experiences and diverging paths. Autonomy development is not something that can be predicted in terms of how, how much and at what level it is going to happen. The process is influenced by a series of factors that go from the context, learners' characteristics to the analyses of whom is observing. Nevertheless, we think that it is still the best way to understand better how the process of autonomy development happens.

After giving some thought to learner autonomy perspectives, be it pedagogically critical or not, we perceive a trend towards the idea that autonomy should not be confined to the individual but also to his relation with the world. If the context is taken into consideration in the educational setting, a whole new horizon opens up, and a need to rethink our roles is required.

To finish, we will leave the reader with Freire's words:

The oppressed, having internalized the image of the oppressor and adopted his guidelines are fearful of freedom. Freedom would require them to eject this image and replace it for autonomy and responsibility. Freedom is acquired by conquest, not by gift. It must be pursued constantly and responsibly. Freedom is not an idea located outside of men, nor is it an idea which becomes myth. It is rather the indispensable condition for the quest for human completion. (Freire1998: 2)

Recebido em maio de 2008 Aprovado em dezembro de 2008 E-mail: nicolaides@terra.com.br verafernandes@terra.com.br

\section{REFERENCES}

Auerbach, E. R. 2000. Creating participatory learning communities: Paradoxes and possibilities. In: J. K. Hall, W. G. Eggington. The sociopolitics of English language teaching. Clevedon: Multilingual Matters. Benson, P. and P. Voller 1997. Introduction: Autonomy and independence in language learning in P. Benson and P. Voller (Eds). Autonomy and independence in language learning. London: Longman. 
. 2001. Teaching and Researching Autonomy in Language Learning. Malaysia: Pearson Education Limited.

Boud, D. (ed.). 1988. Moving towards autonomy. In: D. Boud (ed.) Developing Student Autonomy in Learning. Second Edition. London: Kogan Page.

Dam, L. e Legenhausen, L. 1999. Language Acquisition in an autonomous learning environment: learners' self-evaluation and external assessments compared. In: Learner Autonomy in Language Learning: Defining the Field and Effecting Change. Frankfurt am Main: Peter Lang Verlag.

Encyclopædia Britannica Premium Service. In: Encyclopadia Britannica. http://www.britannica.com . Accessed on April 13, 2007.

Dickinson, L. 1987. Self-instruction in Language Learning. Cambridge: Cambridge University Press.

Fernandes, V. Nicolaides, C. S. 2005. Oralidade na LE e ensino formal a trajetória de Lucas. Trabalho apresentado no Seminário Nacional de Linguagem e Ensino - SENALE. Pelotas: UCPel.

Freire, P. 1973. Pedagogy of the Oppressed. Harmondswoth: Penguin. . 1998. Pedagogy of Freedom. Maryland: Roman and Littlefield.

GadotTI, M. Border Crossing: Freirean method and experiences. http:// www.paulofreire.org/Biblioteca/frontera_i.html. Accessed on March 15, 2008.

Holec, H. 1981. Autonomy in Foreign Language Learning. Oxford: Pergamon.

Nicolaides, C. S. 2003. A busca da aprendizagem autônoma de língua estrangeira no contexto acadêmico - PhD Thesis. Porto Alegre: UFRGS.

Parâmetros Curriculares Nacionais: Introdução aos parâmetros curriculares nacionais - Secretaria de Educação Fundamental. Brasília: MEC/SEF, 1997.

Scharle, A. \& Szabó, A. 2000. Learner Autonomy - A guide to developing learner responsibility. Cambridge University Press. 